\title{
The analysis of associations between cytokine network genes and inverse co-morbidity of bronchial asthma and tuberculosis
}

Elena Yu. Bragina ${ }^{*}$, Maxim B. Freidin ${ }^{1}$, Nadezhda P. Babushkina ${ }^{1}$, Anna F. Garaeva ${ }^{1}$, Olga V. Kolokolova ${ }^{1}$, Irina $Z_{\text {h. }}$ Zhalsanova $^{1}$, and Valery P. Puzyrev ${ }^{1,2}$

${ }^{1}$ Research Institute of Medical Genetics, Tomsk NRMC, Tomsk, Russia

${ }^{2}$ Siberian State Medical University, Tomsk, Russia

\begin{abstract}
In the context of the studies of genetic causes of extremely rare co-existence of atopic bronchial asthma (BA) and tuberculosis (TB), an association study was carried out for the polymorphisms of $I L 1 B, I L 8, I L 10, T N F, T N F R S F 1 B$, and CXCL10 genes was carried out in 713 individuals from West Siberia. An association between the rs56061981 polymorphism of CXCL10 gene with TB was found. Also, an association of the rs1800872 variant of IL10 gene with both BA and pulmonary TB was identified. The results suggest the importance of $I L 10$ gene in the development of BA and TB. Further studies of the $I L 10$ signaling pathway will clarify the mechanisms by which the inverse co-morbidity between infectious and allergic diseases develops.
\end{abstract}

\section{$\underline{\text { Introduction }}$}

Co-morbidity, a simultaneous development of several pathologic conditions in one individual, is a common phenomenon in clinical practice [1]. It is a pressing issue in healthcare as the presence of a concomitant disorder would reduce the efficacy of the treatment and may exacerbate the course of the main disease. According to the concept of syntropy/dystropy (often or rare co-morbidity, respectively), an accumulation of co-morbidity in families suggest a non-random nature in the combination of the diseases in individuals and their relatives and, therefore, the importance of genes, called "syntropic genes", which are responsible for their simultaneous development [,3]. In the basis of co-morbidity are such factors as age of the patients and the effects of shared environmental factors [4], as well as pleiotropic effects of genes [5].

The issue of co-morbidity is a specific subject of genetic studies. Using an example of cardiovascular diseases continuum, including a concomitant manifestation of coronary artery disease, type 2 diabetes, arterial hypertension, and hypecholesterinemia, it was shown that genetic profile of such the co-morbidity is remarkably different from the genetic component of the diseases manifesting alone [6].

Unlike co-morbid diseases, dystropic, or inversely co-morbid disorders, are rare in human populations [3,7]. Various factors can participate in the suppression of one disease in the context of the development of another, including so-called dystropic genes [2]. The hypothesis about shared genes that can orchestrate mutual repulsion of diseases is getting more support in recent studies [8]. For instance, based on the epidemiological observations about the decrease of cancer risk in patients with neurodegenerative disorders [9], a transcriptomic meta-analysis was carried out that showed an essential overlap between differentially expressed genes de-regulated in opposite directions [10]. In patients with epidemiologically approved dystropy of osteoporosis and osteoarthrosis, shared genes participating in apoptosis and osteogenesis exhibit remarkably differential expression [11].
In the context of dystropic diseases, it is interesting to approach the problem from the "benefit/harm" point of view. It suggests that the increase of the risk of one group of diseases ("the harm") leads to the decrease of the risk of other group of diseases ("the benefit") [12]. In this regard, the identification of genes, proteins, signaling pathways, and other factors that reduce the risk of a disease in the presence of another disorder, is important for preventing disease manifestation and detection of new drug targets.

Atopic BA and pulmonary TB is a useful model for the study of the mechanisms of mutual exclusion of diseases, because they are known to extremely rare co-occur in the same patient $[13,14]$. Earlier, using systems biology approach, we identified shared genes for these diseases [15]; the genes that can potentially influence the development of dystropic relationships between them. Once the genes have been identified, the next logical step would be to study their association with the diseases of interest. Herewith, we report the results of such the study aimed to carry out the analysis of association of polymorphisms of IL1B, IL8, IL10, TNF, TNFRSF1B, and CXCL10 genes with BA and TB in Russians of West Siberia.

\section{Material and methods}

The study was approved by the Ethical Committee of the Research Institute of Medical Genetics. Signed informed consent was obtained from all the participants. A total of 154 patients with atopic BA were

Correspondence to: Bragina $\mathrm{E} \mathrm{Yu}$, Research Institute of Medical Genetics, Nabereznaya Ushaiki, Tomsk 634050, Russia, Tel: +7 3822 901101; Fax: +7 3822 513744; E-mail: elena.bragina@medgenetics.ru

Key words: Co-morbidity, inverse co-morbidity, syntropy, dystropy, asthma, tuberculosis, IL10 gene, CXCL10 gene

Received: December 02, 2016; Accepted: December 19, 2016; Published: December 22, 2016 
studied (mean age $41.1 \pm 13$ years) including 118 females and 36 males. $\mathrm{TB}$ patients comprised 304 individuals $(30 \pm 16.1$ years $)$ including 107 females and 197 males. The control group included 255 healthy individuals ( $44.8 \pm 21.7$ years) including 194 females and 61 males. All participants were ethnic Russians settled in the city of Tomsk or Tomsk Region.

Seven polymorphisms were studied: IL10 rs180087, IL8 rs4073, IL1B rs16944, TNF rs1800629, TNFRSF1B rs52589, CXCL10 rs4386624 and rs56061981. Genotyping was carried out using either allele-specific real-time PCR with TaqMan assays (Applied Biosystems) or restriction fragments length polymorphism approach (Table 1).

Fisher's exact test was used to assess the polymorphisms for compliance with Hardy-Weinberg equilibrium. Association between the polymorphisms and diseases was established using logistic regression accounting for sex and age as covariates. Additive, dominant and recessive genetic models were tested and the best fit was chosen using Akaike Information Criteria (AIC) [16]. MonteCarlo permutations were used to address the multiple testing issue. Permutation $\mathrm{p}$-value $<0.05$ were considered statistically significant. The analyses were carried out in $\mathrm{R}$ statistical environment.

\section{Results and discussion}

In healthy individuals, all the polymorphisms were present in accordance with the expectation under Hardy-Weinberg equilibrium except for the rs525891 of TNFRSF1B $(\mathrm{p}=0.014)$. An association between the IL10 polymorphism rs 1800872 and the development of BA and TB was found (Table 2). In both cases, additive model provided the best fit (the only statistically significant in case of BA) according to the AIC values. This suggests the increased risks of $B A$ and $\mathrm{TB}$ associated with the rs $1800872^{\star} \mathrm{A}$ allele: $\mathrm{OR}=1.55[1.06-2.27], \mathrm{p}=0.022$ for $\mathrm{BA}$ and $\mathrm{OR}=1.72$ [1.16-2.56], $\mathrm{p}=0.008$ for TB.

As a key anti-inflammatory cytokine, IL-10 is a subject in studies of multiple diseases. It is produced by various immune system cells, including macrophages, B- and T-cells [17]. The major source of $I L$ 10 are sub-populations of T-helper cells such as Th1-, Th2-, Treg- and Th17-cells [18]. $I L-10$ governs immunoregulation and inflammation, can block NF- $\kappa B$ transcription factor activity, is involved in regulation of JAK-STAT signaling pathways. It suppresses expression of proinflammatory cytokines IL-1 $\beta$, IL-6, IL-8, TNF $\alpha$, IL-12 [19]. An inhibition of the function of antigen-presenting cells can be the major mechanisms by which IL-10 regulates antigen-specific populations of

Table 1. Primers and restriction enzymes for the studied polymorphisms.

\begin{tabular}{|c|c|c|}
\hline Gene (polymorphism) & Primers & Restriction endonuclease and restriction fragments \\
\hline \multirow[t]{2}{*}{ IL10 (rs1800872) } & F: 5'- ggtcatggtgagcactacct & Rsa I \\
\hline & R: 5'- aaaaagttgatttcetgggg & A: $311+182 ; C: 493$ \\
\hline \multirow[t]{2}{*}{$I L 1 B(\mathrm{rs} 16944)$} & F: 5'- gccctccctgtctgtattga & Ama87 I \\
\hline & R: 5'- tggctagggtaacagcacct & A: $222 ; \mathrm{G}: 166+56$ \\
\hline \multirow[t]{2}{*}{ IL8 (rs4073) } & F: 5 '- cttgttctaacacctgccactc & Mfe I \\
\hline & R: 5'- ggcaaacctgagtcatcaca & T: $222 ; \mathrm{A}: 141+81$ \\
\hline \multirow[t]{2}{*}{ TNFRSF1B (rs525891) } & F: 5'-catggaagctctttccttgc & Hpy188III \\
\hline & R: 5'-gttttgtctgccetgctctc & T: $347 ;$ A: $280+67$ \\
\hline \multirow[t]{2}{*}{$T N F(\mathrm{rs} 1800629)$} & F: 5'-aggcaataggttttgagggccat & Bsp19 I \\
\hline & R: 5'- tcctccetgctccgattccg & A: $107 ; \mathrm{G}: 87+20$ \\
\hline CXCL10 (RS4386624) & $\begin{array}{l}* \\
*\end{array}$ & * \\
\hline \multirow[t]{2}{*}{ CXCL10 (rs56061981) } & F: 5'- gcagatactgtctcagaacctggta & Xba I \\
\hline & R: 5'- tgtcaccatctctcattttgattgt & G: $499 ; A: 325+174$ \\
\hline
\end{tabular}

* genotyping was carried out using real-time PCR and TaqMan ${ }^{\circledR}$ Assays (Applied Biosystems).

Th-cell, and adaptive immune response as a whole, to limit pathological condition [20].

Complex regulation of the expression of $I L-10$ complicates understanding the mechanisms by which this cytokine exhibit its biological effects in different diseases. In particular, in the case of infectious disease, anti-inflammatory capacity of $I L-10$ may lead to a paradox situation whereby the initiation of inflammation is critical for effective defence, but its over-activity can lead to the development of inflammatory, autoimmune and oncologic diseases [21]. This mechanism is of interest for the explanation of the possible role of the IL10 gene in the development of dystropic relationships between BA and TB - effective defence against mycobacteria prevents from the development of TB, but increases the risk of BA due to expansion of inflammatory environment. This hypothesis required further experimental validation.

Heritability estimates for $I L-10$ levels obtained in twin studies lie in between $50 \%$ to $75 \%$ [22] suggesting essential genetic contribution in manifestation of this trait. Selective pressure on the IL10 gene alleles by various pathogens during evolution allowed forming different haplotypic blocks influencing the levels of production of this cytokine [23]. The studied rs 1800872 polymorphism is a G-to-A substitution in promoter region of the gene; it is a part in the haplotype comprised of rs1800896, rs180087, and rs1800872 polymorphisms that possibly influence $I L 10$ gene expression.

The data on what particular allele or genotype of the rs1800872 is associated with $\mathrm{BA}$ and $\mathrm{TB}$ is controversial. In one study, the rs $1800872^{\star} \mathrm{C}$ allele and CC genotype are the risk factors for BA [24], while in another it is the alternative rs1800872*A allele [25]. Same controversies are seen for association between IL10 and TB, too [26]. The current study demonstrated that the risk of both $\mathrm{BA}$ and $\mathrm{TB}$ is elevated by the $\mathrm{rs} 1800872^{\star} \mathrm{A}$ allele associated with the decreased production of the cytokine [27].

Another association revealed in the current study concerns the rs56061981 polymorphism of CXCL10 chemokine gene and TB (Table 2). Additive model was the best according to AIC, though dominant model was very similar. The genetic variant is a G-to-A substitution in the promoter of the gene. Rare A allele was more common in TB patients as compared to control (7.8\% vs $3.0 \%$, respectively). To the best of our knowledge, this association was found for the first time.

Chemokines play crucial role in anti-bacterial defence as they serve as early inflammatory mediators in response to infectious agent 
Table 2. The results of the analysis of association between the variants of CXCL10 (rs56061981) and $I L 10$ (rs1800872) genes and the studied diseases.

\begin{tabular}{|c|c|c|c|c|c|c|c|c|c|c|c|c|}
\hline \multirow[t]{2}{*}{ Polymorphism } & \multirow{2}{*}{$\begin{array}{l}\text { Genotypes/ } \\
\text { Alleles }\end{array}$} & \multirow{2}{*}{\begin{tabular}{|l|} 
Control \\
N (\%)
\end{tabular}} & \multirow{2}{*}{\begin{tabular}{|l|}
$\begin{array}{l}\text { Bronchial } \\
\text { asthma }\end{array}$ \\
$\mathbf{N}(\%)$
\end{tabular}} & \multirow{2}{*}{\begin{tabular}{|l|} 
Tuberculosis \\
N (\%) \\
\end{tabular}} & \multicolumn{4}{|c|}{ Bronchial asthma } & \multicolumn{4}{|c|}{ Tuberculosis } \\
\hline & & & & & Model & P-perm & OR [CI] & AIC & Model & P-perm & OR [CI] & AIC \\
\hline \multirow[t]{4}{*}{ IL10 ( $\mathrm{rs} 1800872)$} & $\mathrm{C} / \mathrm{C}$ & $147(67.8)$ & $71(57.7)$ & $131(56.0)$ & Additive & 0.022 & $1.55[1.06-2.27]$ & 442.13 & Additive & 0.008 & $1.72[1.16-2.56]$ & 442.12 \\
\hline & $\mathrm{C} / \mathrm{A}$ & $63(29.0)$ & $42(34.2)$ & $88(37.6)$ & Dominant & 0.058 & $1.55[0.98-2.47]$ & 443.82 & Dominant & 0.022 & $1.73[1.08-2.78]$ & 444.26 \\
\hline & $\mathrm{A} / \mathrm{A}$ & $7(3.2)$ & $10(8.1)$ & $15(6.4)$ & Recessive & 0.052 & $2.71[1.01-7.69]$ & 443.42 & Recessive & 0.040 & $0.75[0.41-1.36]$ & 539.31 \\
\hline & C, $\%$ & 82.3 & 74.8 & 74.8 & & & & & & & & \\
\hline \multirow{4}{*}{\begin{tabular}{|l} 
CXCL10 \\
(rs56061981)
\end{tabular}} & $\mathrm{G} / \mathrm{G}$ & $202(94.4)$ & $133(91.1)$ & $250(85.6)$ & Additive & $>0.05$ & - & - & Additive & 0.013 & $2.46[1.24-5.26]$ & 482.54 \\
\hline & G/A & $11(5.1)$ & $13(8.9)$ & $39(13.4)$ & Dominant & $>0.05$ & - & - & Dominant & 0.010 & 2.77 [1.27-6.47] & 482.61 \\
\hline & $\mathrm{A} / \mathrm{A}$ & $1(0.5)$ & $0(0.0)$ & $3(1.0)$ & Recessive & $>0.05$ & - & - & Recessive & 0.010 & $9.09[3.08-28.98]$ & 529.89 \\
\hline & $\mathrm{G}, \%$ & 97.0 & 95.6 & 92.2 & & & - & - & & & & \\
\hline
\end{tabular}

intervention [28]. Chemokines induce effector cell migration into the focus of infection. A response to infection differs depending on the levels of expression of CXCL10 gene [29]; thus, its promoter variants influencing the affinity of the sites for transcription factor binding and, therefore, affecting the gene expression, are of interest for the studies of genetic ground of susceptibility to infectious diseases. Earlier, other promoter variants of CXCL10 gene were shown to be associated with TB [30].

Thus, the study revealed an association between rs1800872 polymorphism of IL10 both with BA and TB, suggesting the involvement of shared molecular pathways in their pathogenesis. Also, possible impact of the rs56061981 polymorphism of CXCL10 gene on the development of TB was established for the first time. The results are of interest both for the understanding of the mechanisms of the phenomenon of dystropy and for the delineating genetic factors of susceptibility to $\mathrm{BA}$ and $\mathrm{TB}$ alone.

\section{Funding}

The study was supported by the grant of the Russian Foundation for Basic Research \#15-04-05852.

\section{References}

1. Jacob L, Breuer J, Kostev K (2016) Prevalence of chronic diseases among older patients in German general practices. Ger Med Sci 14: Doc03. [Crossref]

2. Puzyrev VP, Freidin MB (2009) Genetic view on the phenomenon of combined diseases in man. Acta Naturae 1: 52-57. [Crossref]

3. Puzyrev VP, Makeeva OA, Freidin MB (2010) Syntropy, genetic testing and personalized medicine. Personalized Medicine 7: 399-405. [Crossref]

4. Bagley SC, Sirota M, Chen R, Butte AJ, Altman RB (2016) Constraints on Biological Mechanism from Disease Comorbidity Using Electronic Medical Records and Database of Genetic Variants. PLoS Comput Biol 12: e1004885. [Crossref]

5. Hu JX, Thomas CE, Brunak S (2016) Network biology concepts in complex disease comorbidities. Nat Rev Genet 17: 615-629. [Crossref]

6. Puzyrev VP (2015) Genetic basis of human comorbidity. Rus J Genet 51: 408-417. [Crossref]

7. Pfaundler M, von Seht L (1921) Über Syntropie von Krankheitszuständen. Zeitschrift für Kinderheilkunde 30: 100-120. [Crossref]

8. Puzyrev VP, Freidin MB (2009) Genetic view on the phenomenon of combined diseases in man. Acta Naturae 1: 52-57. [Crossref]

9. Catalá-López F, Suárez-Pinilla M, Suárez-Pinilla P (2014) Inverse and direct cancer comorbidity in people with central nervous system disorders: a meta-analysis of cancer incidence in 577,013 participants of 50 observational studies. Psychot Psychosom 83: 89-105. [Crossref]

10. Ibáñez K, Boullosa C, Tabarés-Seisdedos R, Baudot A, Valencia A (2014) Molecular evidence for the inverse comorbidity between central nervous system disorders and cancers detected by transcriptomic meta-analyses. PLoS Genet 10: e1004173. [Crossref]
11. Giner M, Montoya MJ, Vázquez MA, Miranda C, Pérez-Cano R (2013) Differences in osteogenic and apoptotic genes between osteoporotic and osteoarthritic patients. BMC Musculoskelet Disord 4: 41. [Crossref]

12. Crespi BJ, Go MC (2015) Diametrical diseases reflect evolutionary-genetic tradeoffs: Evidence from psychiatry, neurology, rheumatology, oncology and immunology. Evol Med Public Health 2015:216-253. [Crossref]

13. Shirtcliffe P, Weatherall M, Beasley R, International Study of Asthma and Allergies in Childhood (2002) An inverse correlation between estimated tuberculosis notification rates and asthma symptoms. Respirology 7: 153-155.

14. Fekih L, Boussoffara L, Jemaa M, Fenniche S, Hassene H, et al. (2010) [Tuberculosis in patients with asthma]. Rev Mal Respir 27: 679-684. [Crossref]

15. Bragina EY, Tiys ES, Freidin MB, Koneva LA, Demenkov PS, et al. (2014) Insights into pathophysiology of dystropy through the analysis of gene networks: an example of bronchial asthma and tuberculosis. Immunogenetics 66: 457-465. [Crossref]

16. Lindsey JK, Jones B (1998) Choosing among generalized linear models applied to medical data. Stat Med 17: 59-68. [Crossref]

17. Groux H, Cottrez F (2003) The complex role of interleukin-10 in autoimmunity. $J$ Autoimmun 20: 281-285. [Crossref]

18. Belkaid Y, Tarbell K (2009) Regulatory T cells in the control of host-microorganism interactions (*). Annu Rev Immunol 27: 551-589. [Crossref]

19. Fiorentino DF, Zlotnik A, Mosmann TR, Howard M, O'Garra A (1991) IL-10 inhibits cytokine production by activated macrophages. J Immunol 147: 3815-3822. [Crossref]

20. Mocellin S, Marincola F, Rossi CR, Nitti D, Lise M (2004) The multifaceted relationship between IL-10 and adaptive immunity: putting together the pieces of a puzzle. Cytokine Growth Factor Rev 15: 61-76. [Crossref]

21. Hedrich CM, Bream JH (2010) Cell type-specific regulation of IL-10 expression in inflammation and disease. Immunol Res 47: 185-206. [Crossref]

22. Gibson AW, Edberg JC, Wu J, Westendorp RG, Huizinga TW, et al. (2001) Nove single nucleotide polymorphisms in the distal $I L-10$ promoter affect $I L-10$ production and enhance the risk of systemic lupus erythematosus. J Immunol 166: 3915-3922. [Crossref]

23. Wilson JN, Rockett K, Keating B, Jallow M, Pinder M, et al. (2006) A hallmark of balancing selection is present at the promoter region of interleukin 10. Genes Immun 7: 680-683. [Crossref]

24. Hakimizadeh E, Arababadi MK, Hassanshahi G, Ahmadabadi BN, Hakimi $\mathrm{H}$, et al. (2012) Association of -592 region of $I L-10$ polymorphisms with asthma in south-eastern Iranian patients. Clin Lab 58: 267-271. [Crossref]

25. Zheng XY, Guan WJ, Mao C, Chen HF, Ding H, et al. (2014) Interleukin-10 promoter 1082/-819/-592 polymorphisms are associated with asthma susceptibility in Asians and atopic asthma: a meta-analysis. Lung 192: 65-73. [Crossref]

26. Mhmoud N, Fahal A, van de Sande WJ (2013) Association of IL-10 and CCL5 single nucleotide polymorphisms with tuberculosis in the Sudanese population. Trop Med Int Health 18: 1119-1127. [Crossref]

27. Lowe PR, Galley HF, Abdel-Fattah A, Webster NR (2003) Influence of interleukin-10 polymorphisms on interleukin-10 expression and survival in critically ill patients. Crit Care Med 31: 34-38. [Crossref]

28. Sauty A, Dziejman M, Taha RA, Iarossi AS, Neote K, et al. (1999) The T cell-specific CXC chemokines IP-10, Mig, and I-TAC are expressed by activated human bronchial epithelial cells. J Immunol 162: 3549-3558. [Crossref] 
Bragina E.Yu. (2016) The analysis of associations between cytokine network genes and inverse co-morbidity of bronchial asthma and tuberculosis

29. Ruhwald M, Bjerregaard-Andersen M, Rabna P, et al. (2007) CXCL10/IP-10 release is induced by incubation of whole blood from tuberculosis patients with ESAT-6, CFP10 and TB7.7. Microbes Infect 9: 806-812. [Crossref]
30. Tang NL, Fan HP, Chang KC, Ching JK, Kong KP, et al. (2009) Genetic association between a chemokine gene $C X C L-10$ (IP-10, interferon gamma inducible protein 10) and susceptibility to tuberculosis. Clin Chim Acta 406: 98-102. [Crossref]

Copyright: $(02016$ Bragina E.Yu. This is an open-access article distributed under the terms of the Creative Commons Attribution License, which permits unrestricted use, distribution, and reproduction in any medium, provided the original author and source are credited. 